\title{
Value-Relevance of Accounting Information: An Empirical Investigation in Certain European Stock Exchanges
}

\author{
Yohanes Indrayono ${ }^{1}$ \\ ${ }^{1}$ Universitas Pakuan, Bogor, West Java, Indonesia \\ Correspondence: Yohanes Indrayono, Doctoral Program of Management Science, Jalan Pakuan, Bogor, West \\ Java, Indonesia. E-mail: yindrayono@gmail.com
}

Received: August 14, 2019

Accepted: August 30, 2019

Online Published: August 31, 2019

doi:10.5539/ijef.v11n9p75

URL: https://doi.org/10.5539/ijef.v11n9p75

\begin{abstract}
This study accommodates the value-relevance of accounting information based on a sample of 165 firms listed in one of the following European stock exchanged: CAC 40, BEL 20, DAX 30, FTSE MIB 40 and IBEX 35 Stock Exchanges for the period 2013-2015. This study uses information about the accounting method of recognizing the accounting value-relevance. This study applied linear analysis-regression to investigate the accounting value-relevance information on one hundred sixty-five firms during the period of three years. This study suggests that the accounting information are value-relevant on all the observed stock exchanges. Results of the study indicates that earnings per-share and book value per-share were found to partially and simultaneously affect positively the firm stock price.
\end{abstract}

Keywords: value-relevance, earnings per-share, book value per-share, European stock exchanges

\section{Introduction}

\subsection{Background}

The value-relevance of accounting information becomes interesting topics for several researches of accounting areas during the last two decades. The empirical studies carried on both developed and developing countries concerning the accounting topic (King \& Langli, 1998; Ali \& Hwang, 2000; Black \& White, 2003. For example, Gjerde et al., 2010; Tsalavoutas et al., 2012; Glezakos et al., 2012; Ahmadi \& Bouri, 2018), show that accounting information (first of all earnings and book value) are considered as the most significant determinant in measurement of firm value and that these variables are significantly related to firm stock prices. In other words, these studies provide that accounting information are value relevant.

The main objective of firm financial reporting is to provide information for prospective users especially from external to be used for decision making of the firm. Investors, creditors, and other external users of financial reporting use information from accounting reporting system to predict concerning the value of the firm. When accounting information system can be used to predict firm market value it is to be considered as value relevant accounting. When the market value of a firm is failed to be predicted using its firm's accounting information system, the firm's accounting information is not considered as value relevant accounting. The full disclosure of all events concerning the firm business during current and subsequent reporting period is a must to make value relevant accounting. Previous studies of Paglietti (2009), Anagnostopoulo and Tsekrekos (2017), Antonakakisa et al. (2017), Robinson et al. (2017), Ahmadi et al. (2018) argued that the value relevant of accounting information is when firm's accounting information able to describe the firm's existing condition and can be visible, understandable, accessible to all market participants.

The last years a high number researches from many countries about value relevance research that were conducted to compare among different capital markets. These researches show that there are some differences in the value relevance of accounting information disclosed by firms. Studies conducted by Arce and Mora (2002); Black and White (2003); Pervana and Bartulović (2014), Joliet and Muller (2016), Houcine (2017); Wang (2017), Wang (2018) show the differences in the value relevance is attributed by the different institutional and legal frameworks. According to the previous researches of accounting relevance information, earnings per share, and book value per share, this study conducts by using accounting data reported by firms which listed in some European capital markets. This study will give understanding to investors and other stock market participants that accounting information is important for their decision making about their investment in stock markets. 
To reach this end, the objective of the paper is twofold. The first one aims to shed light on the value relevance of earnings per share and book value. The second objective is to compare the different capital market of the sample study. The study investigates the relative and incremental value relevance of earning per share and book value of CAC 40, BEL 20, DAX 30, FTSE MIB 40 and IBEX 35 stock markets over the 2013-2015 period using Ohlson (1995) model of firm valuation as a basic. The paper uses a panel regression model of stock market value and earnings/book value to investigate the relative of value-relevance among earning per share and book value. The methodology of testing the value relevance of earning per share and book value is based on partial and simultaneous regressions analyses.

\subsection{Literature Review and Hypothesis}

Since the research of Ball and Brown (1968) several many studies have examined the value relevance of accounting information more precisely the book value, earnings and cash flows. Indeed, many studies show a statistical significant role of information content in equity measurement (Ohlson, 1995; Feltham \& Ohlson, 1995; Easton et al., 1999). More recent research show that the earnings and book value have higher value relevance than the cash flows since the accounting accruals argues a better expectation about forecasting cash flows than does prediction about current cash receipts and payments. Contrarily, Francis and Schipper (1999); Wang et al. (2006), Oswald (2008), Maigoshi et al. (2017), Moumen et al. (2017) shows that the value relevance of earnings has decreased over the study' sample period, whilst the book value has increased.

The study by Rohit and Jayadev (2016) investigates the effect of accounting information of quarterly financial reporting to the firm's risk and return of a sample of 39 listed banks during the period cover 2008-2015 found that stock prices are negatively affect to the increase of non performing assets reported by banks and positively affect to the increase of reported accounting returns. Moreover, the study shows that there are significant differences of the effect of accounting information disclosure to the stock prices' reaction of both public and private sector banks. Risk-related information is more important for firms with low price stock prices, but it is less important for the public sector banks especially with lower accounting returns.

Other studies by Marquardt and Wiedman (2004) argued that firm's earnings management to avoid losses and the decrease of earnings can cause a deterioration of the value relevance of firm' earnings. Hadi (2004) investigates the value relevance of accounting information of the investors in Kuwaiti banks listed in stock exchange market using six financial ratios with regression analysis to resolve the purpose of the study. The result shows that in decision making, investors use the accounting information in Kuwaiti banks so that , most ratios are significant except for the loss ratio. In another study, Sbei and Trabelsi (2014) also investigate the value relevance of accounting information for the banks listed in the Dubai Financial Market, and the result shows that the accounting information is correlated to firm market value. Using several accounting ratios to examine the value relevance of accounting information in the Colombo Stock Exchange, Vijltha and Nimalathasan (2014) show a significant effects of earnings per share, net asset value per share and return on equity on the share prices of listed firms on the stock exchange. The other several studies conduct in different European contexts such those of Wang et al. (2006); Inchaustirt al. (2007); Oswald (2008); Cormier et al. (2009); Devalle and Magarini (2012) show that earnings per-share affect to the stock prices.

From the above discussion it can be derived a hypothesis:

H1: Firm's earning per-share positively affect stock price.

Glezakos, et al., (2012) examine the association between earnings per-share and book values per-share on share prices of Athens Stock Exchange firms; they show that the explanatory power of earnings per share and book value in stock prices had increased over time. Also they provide that in the last years the earnings played an increasingly declining mission in the stock prices relative to book values of the latest sample. Referring to the research of O'Hanlon and Pope (1999); Cormier et al. (2009), Agostino et al. (2010); Inchausti and Pérez (2011); Devalle and Magarini (2012), Vo (2017), Robinson et al. (2017), the book value has a positive effect on the stock price valuation. From the above discussion it can be derived a hypothesis:

H2: Firm's book value per-share positively affect stock price.

\section{Method}

\subsection{Research Design}

Barth et al. (2001) argued that the firm's accounting figure can be considered as value-relevant if it is correlated to the firm' stock price. Several previous studies have been conducted and show that the value relevance occur through the relationship between the earnings, variations and stock returns value. These studies used regression analyses and show that the regression coefficient can measure the relevance of an accounting information. 
Indeed, the lower coefficient reflects the lower relevance of a disclosed accounting information. This study uses one main dependent variable which is the firm' stock price is taken as the adjusted close price of firm stocks. The adjusted close prices at the period of three months after the fiscal year end are collected from Data Stream to ensure that the accounting information was available and had been absorbed by investors and all market participants that they can be used in their decision making process (Tsalavoutas et al., 2012). This study uses a quantitative approach using multiple regression analysis. In this area, we try contribute to the accounting literature on the quality of financial reports by showing the importance of firm's earning per share and book value on the explanation of variation of firm's stock price. It is important to to evaluate whether the value relevance of financial statements can reflect the information that has affected firm' market price in the relationship to earning per share and book value per share.

This study uses the model of Ohlson (1995) to determine the value relevance of earnings per share and book value per share. This model expresses firm stock market price $(\mathrm{P})$ as a function of both earnings per-share (EPS) and book value per-share (BV).

where:

$$
P i t=\alpha 0+\beta_{1} \text { EPSit }+\beta_{2} \text { BVit }+e i t
$$

Pit - is the stock price of 3 months after the end of fiscal year $t$, where year $t$ is the event year.

EPSit - is firm's earnings per-share in year $\mathrm{t}$,

BVit - is book value per-share at the end of year $\mathrm{t}$,

eit - is error term for firm $\mathrm{i}$ in year $\mathrm{t}$.

\subsection{Sample Selection}

This study was conducted on selected firms whose firm's stocks are listed in CAC 40 (40 firms), DAX 30 (30 firms), FTSE MIB 40 (40 firms) and IBEX 35 (35 firms) and BEL 20 (20 firms) listed in Stock Exchanges for the period 2013-2015. These stock markets are considered as the most important European capital market and there are from the first worldwide ones. This study is to investigate the relationship between the earning per-share, book value per-share and firm's stock price basically use a generalized version of the Ohlson (1995) model.

The sample consists of 165 firm listed on CAC 40, BEL 20, DAX 30, FTSE MIB 40 and IBEX 35 Stock Exchanges during the period 2013-2015. Data are taken from the official site of the Data Stream (Worldscope) the final sample contain 495 observations firms-year which include data of the 3-years period from 2013 to 2015 of five European stock markets.

\section{Results}

Table 1. shows the descriptive statistics of mean, standard deviation, minimum, maximum of earning per share (EPS), book value per share (BV) and firm stock price $(\mathrm{P})$ for firms as a sample in certain European stock markets (FTSE MIB, CAC 40, DAX, IBEX and BEL 20) during the period of 3 years from 2013 to 2015. Earning per-share derived from firm's income statement which is the yearly net earning after tax divided by the number of firm's stocks issued. Book value per share is derived from firm's balance sheet which is the net assets of all liabilities at the end of each yearly accounting period divided by the number of firm's stocks issued.

Comparatively each index capital market to other we can see that the high value of price per share are classified respectively as the firms listed in the FTSE MIB, CAC 40, DAX, IBEX and BEL 20. The same scale is seen in earning per-share and the high value are taken by the firm listed in the CAC 40, FTSE MIB 40. With reference to the variables used in the price regression model, there are few cases where the country mean significantly differs from the mean of the other countries. The mean of P, EPS, and BV of FTSE MIB - are higher in comparison with the same ratio of the other countries.

Table 1. Descriptive statistics

\begin{tabular}{|c|c|c|c|c|c|}
\hline Variable & Index & Mean & Std. Deviation & Minimum & Maximum \\
\hline \multirow{5}{*}{$\mathrm{P}$} & CAC 40 & 46,557 & 29,608 & 5,952 & 151,650 \\
\hline & DAX 31 & 28,758 & 16,481 & 4,185 & 116,450 \\
\hline & IBEX 36 & 22,681 & 15,171 & 3,178 & 103,960 \\
\hline & FTSE MIB & 53,968 & 32,081 & 7,751 & 172,220 \\
\hline & BEL 20 & 14,236 & 9,608 & $-0,555$ & 80,790 \\
\hline \multirow{3}{*}{ EPS } & CAC 40 & 3,752 & 1,888 & $-0,555$ & 5,330 \\
\hline & DAX 31 & 3,223 & 2,002 & $-2,123$ & 4,900 \\
\hline & IBEX 36 & 2,088 & 1,640 & $-1,840$ & 3,550 \\
\hline
\end{tabular}




\begin{tabular}{rlrrrr} 
& & & & $-2,627$ & 6,752 \\
\cline { 2 - 6 } & FTSE MIB & 4,117 & 2,333 & $-0,627$ & 5,330 \\
\hline BEL 20 & 3,658 & 1,903 & 0,666 & 103,317 \\
& CAC 40 & 25,101 & 21,059 & 0,521 & 83,168 \\
BV & DAX 31 & 17,118 & 11,059 & 1,012 & 68,317 \\
& IBEX 36 & 22,220 & 16,133 & 1,110 & 114,750 \\
& FTSE MIB & 31,990 & 22,446 & 1,003 & 97,321 \\
\hline
\end{tabular}

Regression model is estimated to assess whether the book value and earning per share, which have been used to predict the researches' questions, are relevant in the determination of stock price value of firm listed in the European stock exchange market.

Table 2. Estimation results: Pit $=\alpha 0+\beta 1 E P S i t+\beta 2 B V i t+e i t$

\begin{tabular}{cccccc}
\hline Variables & CAC40 & DAX30 & FTSE-MIB & IBEX35 & BEL20 \\
\hline$\beta_{1}$ & .412532 & .332152 & .444499 & .291083 & .221359 \\
& $0.005^{* * *}$ & $0.082^{*}$ & $0.000^{* * *}$ & $0.031^{* *}$ & $0.092^{*}$ \\
\hline$\beta_{2}$ & .946593 & 0.4224 & .969129 & .57774 & .378821 \\
& $0.000^{* * *}$ & $0.012^{* *}$ & $0.000^{* * *}$ & $0.080^{*}$ & $0.009^{* * *}$ \\
\hline $\mathrm{N}$ (number of observation per country) & 120 & 90 & 120 & 105 & 60 \\
\hline $\mathrm{R}$ square & 0.5740 & 0.3411 & 0.5465 & 0.3488 & 0.3102 \\
\hline $\mathrm{F}$ (H0: $\alpha \mathrm{i}=0)$ & 30.16 & 16.331 & 44.547 & 14.71 & 12.33 \\
& $0.000^{* * *}$ & $0.000^{* * *}$ & $0.000^{* * *}$ & $0.000^{* * *}$ & $0.000^{* * *}$ \\
\hline
\end{tabular}

$* * *=99 \% \mathrm{CL} ; * *=95 \% \mathrm{CL} ; *=90 \% \mathrm{CL}$.

Table 2 shows the results of the within-group estimation of the price regression model as specified in the regression model. As we can see from Table 2. the R square value (using regression model) is higher in CAC40 listed firms than in the other stock market tested in our study. According to Table 2, we can notice higher R2 values regarding CAC40, DAX30, FTSE- MIB, IBEX35 and BEL20, we can confirm the independent variables allow to explain the variation of independent variable, these results are confirmed by the value taken by f-statistics which support the importance of earning per-share and book value in the determination of firm's stock price.

The findings show that the $\beta_{1}$ is statistically significant of all listed companies in all market index of our study CAC 40 listed companies ( $\mathrm{p}$-value $<0.01$ ); DAX30 listed firms ( $\mathrm{p}$-value $<0.1$ ); in FTSE MIB listed companies (p-value < 0.01); in IBEX35 listed firms (p-value < 0.05); in BEL 20 listed companies ( $\mathrm{p}$-value < 0.1); these results reflect the importance of implication of earning per-share in the explanation of stock market price. Hypothesis 1 supported.

According to the predict sign and to the result of previous studies the findings show that the $\beta_{2}$ is statistically significant of all listed companies in all market index of our study in a high level of significance CAC 40 listed companies (p-value < 0.01); DAX30 listed firms ( -value < 0.05); in FTSE MIB listed companies (p-value < 0.01 ); in IBEX35 listed firms (p-value < 0.1); in BEL 20 listed companies (p-value < 0.01); these results reflect the importance of implication of earning per-share in the explanation of stock market price. Hypothesis 2 supported.

\section{Discussion}

This study is to empirically examine the value relevance of accounting information in several European capital market in order to ascertain whether certain accounting variables have the ability to explain the valuation of stock price on the CAC 40, BEL 20, DAX 30, FTSE MIB 40 and IBEX 35 Stock Exchanges. The research design of this study refers to the model of price valuation of Ohlson' price to present the regression results. The paper provides strong evidence to value relevance of accounting information in the price model valuation of all countries stock exchanges. The study was motivated by literature review in the several contexts in both of the developed and developing countries.

This study has been undertaken to assess the relationship between two accounting variables of firm profitability which is earning per-share and equity value which is book value and firm stock market price. The results of this study shows a strong relationship relationship of each variable and the firm's stock market value. This study supports the previous studies, for examples studies by Wang et al. (2006); Inchaustirt al. (2007); Oswald (2008); Cormier et al. (2009); Devalle and Magarini (2012) that accounting information i.e. firm profit information positively affect firm stock price. This study also supports the previous studies, for examples studies by 
O'Hanlon and Pope (1999); Cormier et al. (2009), Agostino et al. (2010); Inchausti and Pérez (2011); Devalle and Magarini (2012), Vo (2017), Robinson et al. (2017) that accounting information i.e. book value information positively affects firm stock price.

Hence it is apparently assumed that in the European stock exchanges, firm's accounting information is properly reflected on stock market price or the stock price is significantly influenced by the accounting variables. This can be assumed also that most of investors in several European stock markets use firm's accounting information which are earning per-share and book value when they make their decision making about their investments. Overall, the implication of this study is the suggestion for the investors and market participants that they should have more basic knowledge of accounting information about business and economics when they make their decision in the stock markets.

However, this study has several limitations because of lacking firms' data of 2 (two) independent variables which obtained from only 5 countries' index and 3 year-period as a sample of this study. To increase the predictability of the study, future studies should be done with more accounting variables and firms data samples which include all of European stock markets. To provide comparison, the other studies should also be done with firms' data of countries in other regions in the world.

\section{Acknowledgments}

We would like to thank to Ali Ahmadi the lecturer of Accounting Department of Sfax University, Tunisia who had given me manuscript writing support with Peerwith Services.

\section{References}

Agostino, M., Drago, D., \& Silipo, D. (2010). The value relevance of IFRS in the European banking industry. Review of Quantitative Finance and Accounting, 20(June), 1-21

Ahmadi, A., \& Bouri, A. (2018). The accounting value relevance of earnings and book value: Tunisian banks and financial institutions. International Journal of Law and Management. https://doi.org/10.1108/IJLMA-11-2016-0131

Ahmadi, A., Garraoui, M., \& Bouri, B. (2018). The Value Relevance of Book Value, Earnings Per Share and Cash Flow: Evidence of Tunisian Banks and Financial Institutions. International Academic Journal of Accounting and Financial Management, 5(1), 47-56.

Akarim, Y. D., Celik, S., \& Zeytinoglu, E. (2012). The Causality Relationship between Accounting Earnings and Stock Returns in the Light of Value Relevance Theory. Journal of Money, Investment and Banking, 25, 194-198.

Anagnostopoulou, S. C., \& Tsekrekos, A. E. (2017). Accounting quality, information risk and the term structure of implied volatility around earnings announcements. Research in International Business and Finance, 41(C), 445-460. https://doi.org/10.1016/j.ribaf.2017.04.046

Antonakakisa, N., Gupta, R., \& Tiwaric, K. A. (2017). Has the correlation of inflation and stock prices changed in the United States over the last two centuries? Research in International Business and Finance, 42, 1-8. https://doi.org/10.1016/j.ribaf.2017.04.005

Arce, M., \& Mora, A. (2002). Empirical evidence of the effect of European accounting differences on the stock market valuation of earnings and book value. The European Accounting Review, 11, 573-599. https://doi.org/10.1080/09638180220125616

Black, E., \& White, J. (2003). An international comparison of income statement and balance sheet information: Germany, Japan and the US. European Accounting Review, 12, 29-46. https://doi.org/10.1080/0963818022000001127

Cormier, D., Demaria, S., Lapointe-Antunes, P., \& Teller, R. (2009). First-time adoption of IFRS, managerial incentives, and value-relevance: Some French evidence. Journal of International Accounting Research, 8(2), 1-22. https://doi.org/10.2308/jiar.2009.8.2.1

Devalle, A., \& Magarini, R. (2012). Assessing the value relevance of total comprehensive income under IFRS: An empirical evidence from European Stock Exchanges. International Journal of Accounting, Auditing and Performance Evaluation, 8(1), 43-68. https://doi.org/10.1504/IJAAPE.2012.043965

Glezakos, M., Mylonakis, J., \& Kafuoros, C. (2012). The impact of accounting information on stock prices: Evidence from Athens stock exchange. International Journal of Economics and Finance, 4(2), 56-68. https://doi.org/10.5539/ijef.v4n2p56 
Houcine, A. (2017). The effect of financial reporting quality on corporate investment efficiency: Evidence from the Tunisian stock market. Research in International Business and Finance, 42, 321-337. https://doi.org/10.1016/j.ribaf.2017.07.066

Inchausti, B. G., \& Pérez, F. P. (2011). La relevanciavalorativa del resultado global frente al resultadoneto: Unaperspectiva europea. Spanish Journal of Finance and Accounting / Revista Española de Financiación y Contabilidad, 40(150). https://doi.org/10.1080/02102412.2011.10779705

Inchausti, B. G., Pérez, f. P., De Lema, D. G. P., \& Maya, R. C. (2007). The value relevance of goodwill and goodwill amortization: A European perspective. Spanish Journal of Finance and Accounting / Revista $\begin{array}{lllll}\text { Española de Financiación } y & \text { Contabilidad, } & 36(134), & 389-419 .\end{array}$ https://doi.org/10.1080/02102412.2007.10779625

Joliet, R., \& Muller, A. (2016). Are foreign earnings disclosures value-relevant?: Disaggregation solves the puzzle 。 Research in International Business and Finance, 37, 170-183. https://doi.org/10.1016/j.ribaf.2015.09.009

Maigoshi, Z., Abdul, L. R., \& Kamardin, H. (2017). Change in value-relevance of disclosed RPT across accounting regimes: Evidence from Malaysia. Research in International Business and Finance, 44, 422-433. https://doi.org/10.1016/j.ribaf.2017.07.114

Moumen, N., Ben Othman, H., \& Hussainey, K. (2017). The value relevance of risk disclosure in annual reports: Evidence from MENA emerging markets. Research in International Business and Finance, 34, 177-204. https://doi.org/10.1016/j.ribaf.2015.02.004

O'Hanlon, J., \& Pope, P. F. (1999). The value relevance of UK dirty surplus accounting flows'. British Accounting Review, 31, 45-48. https://doi.org/10.1006/bare.1999.0116

Oswald, D. (2008). The determinants and value relevance of the choice of accounting for research and development expenditures in the United Kingdom. Journal of Business Finance \& Accounting, 35(1)\&(2), 1-24. https://doi.org/10.1111/j.1468-5957.2007.02060.x

Paglietti, P. (2009). Earnings management, timely loss recognition and value relevance in Europe following the IFRS mandatory adoption: Evidence from Italian listed companies. Business and Management Sciences International Quarterly Review, 4, 97-117.

Pervana, I., \& Bartulović, M. (2014). Value relevance of accounting information: Evidence from South Eastern European countries. Economic Research-EkonomskaIstraživanja, 27(1), 181-190. https://doi.org/10.1080/1331677X.2014.947132

Robinson, J., Glean, A., \& Moore, W. (2017). How does news impact on the stock prices of green firms in emerging markets? Research in International Business and Finance. https://doi.org/10.1016/j.ribaf.2017.07.176

Tsalavoutas, I., Andre, P., \& Evans, L. (2012). The transition to IFRS and the value relevance of financial statements in Greece. British Accounting Review, 44(4), 262-277. https://doi.org/10.1016/j.bar.2012.09.004

Vo, X. V. (2017). Do foreign investors improve stock price informativeness in emerging equity markets? Evidence from Vietnam. Research in International Business and Finance, 42, 986-991. https://doi.org/10.1016/j.ribaf.2017.07.032

Wang, B. (2018). Ownership, institutions and firm value: Cross-provincial evidence from China. Research in International Business and Finance, 44, 547-565. https://doi.org/10.1016/j.ribaf.2017.07.125

Wang, L. H. (2017). Accounting quality and information asymmetry of foreign direct investment firms. Research in International Business and Finance, 42, 950-958. https://doi.org/10.1016/j.ribaf.2017.07.029

Wang, Y., Buijink, W., \& Eken, R. (2006). The value relevance of dirty surplus accounting flows in The Netherlands. The International Journal of Accounting, 41, 387-405. https://doi.org/10.1016/j.intacc.2006.09.005

\section{Copyrights}

Copyright for this article is retained by the author(s), with first publication rights granted to the journal.

This is an open-access article distributed under the terms and conditions of the Creative Commons Attribution license (http://creativecommons.org/licenses/by/4.0/). 